PENGARUH MODEL PEMBELAJARAN SOMATIC, AUDITORY, VISUAL, DAN INTELLECTUALLY (SAVI) TERHADAP HASIL BELAJAR IPA

\title{
THE INFLUENCE OF SOMATIC, AUDITORY, VISUAL, AND INTELLECTUALLY (SAVI) LEARNING MODELS ON SCIENCE LEARNING OUTCOMES
}

\author{
Baiq Annisa Yuliana ${ }^{1}$, Moh. Liwa Ilhamdi ${ }^{12^{*}}$, dan Heri Hadi Saputra ${ }^{1}$ \\ ${ }^{1}$ Program Studi PGSD, FKIP, Universitas Mataram, Indonesia. \\ ${ }^{2}$ Program Studi Pendidikan Biologi FKIP Universitas Mataram, Mataram, Indonesia \\ *Email: liwa_ilhamdi@unram.ac.id
}

Diterima: 26 Agustus 2021. Disetujui: 26 Agustus 2021. Dipublikasikan: 4 September 2021

\begin{abstract}
Abstrak: Penelitian ini bertujuan untuk mengetahui adakah pengaruh model pembelajaran SAVI terhadap hasil belajar IPA materi macam-macam gaya kepada siswa kelas IV di SDN 1 Sandik. Jenis penelitian yang digunakan adalah Quasi Eksperimen Design Tipe Nonequivalent Control Group Design. Teknik sampling yang digunakan adalah purposive sampling. Jumlah keseluruhan sampel adalah 60 siswa. Adapun analisis data pada penelitian ini menggunakan SPSS versi 21.0 for windows. Uji statistik pada penelitian ini menggunakan uji t dan uji gain ternormalisasi. Berdasarkan hasil nilai rata-rata kelas eksperimen mengalami perubahan yaitu dari nilai pre-test sebesar 56,40 dan nilai posttest sebesar 71,57. Hasil analisis data perhitungan statistic dengan menggunakan uji t (paired-sample t-test) diperoleh 6,931>2,045, maka $\mathrm{H}_{\mathrm{a}}$ diterima dan $\mathrm{H}_{0}$ ditolak. Uji gain ternormalisasi dilakukan untuk mengetahui seberapa besar pengaruh. Hasil uji gain ternormalisasi yang peneliti dapat sebesar 0,3 sesuai dengan katagori skor gain ternormalisasi termasuk kedalam katagori sedang. Penelitian ini menunjukkan bahwa adanya pengaruh model pembelajaran SAVI terhadap hasil belajar IPA siswa kelas IV di SDN 1 Sandik.
\end{abstract}

Kata kunci: Model Pembelajaran SAVI, Hasil Belajar Dan IPA

\begin{abstract}
This study aims to determine the effect of the SAVI learning model on the science learning outcomes of various styles of materials on the fourth-grade elementary students at SDN 1 Sandik, Lombok, Indonesia. The type of research used is quasi-experiment design type nonequivalent control group design. The sampling technique used is purposive sampling. The total number of samples is 60 students. The data analysis in this study used SPSS version 21.0 for windows. The statistical test in this study used the t-test and the normalized gain test. Based on the results, the average value of the experimental class changed, namely from the pre-test value of 56.40 and the post-test value of 71.57. The results of statistical calculation data analysis using the t-test (paired-sample t-test) obtained 6,931 > 2,045. A normalized gain test is done to find out how significant the effect is. The results of the normalized gain test that the researcher got were 0.3 by the normalized gain score category included in the medium category. This study shows an effect of the SAVI learning model on the science learning outcomes of fourth-grade students at SDN 1 Sandik.
\end{abstract}

Keywords: SAVI Learning Model, Learning Outcomes and Science

\section{PENDAHULUAN}

Keberhasilan pelaksanaan pembelajaran sangat tergantung pada pedidik atau guru dalam melaksanakan kegiatan belajar mengajar. Keberhasilan pendidik adalah siswa menjadi generasi yang memiliki kecerdasan intelektual dan spiritual dengan mampu menerima serta mengembangkan ilmu yang diberikan oleh pendidik [1]. Keberhasilan dalam pelaksanaan proses pembelajaran dapat mempengaruhi hasil belajar.

Hasil belajar terdiri dari dua kata yakni, belajar dan hasil [2]. Belajar pada hakikatnya adalah proses interaksi terhadap semua situasi yang ada di sekitar individu [3]. Hasil belajar adalah realisasi dari kecakapan potensial yang dimiliki oleh seseorang [4]. Hasil belajar adalah hasil penilaian yang didapatkan secara individu oleh siswa setelah proses pembelajaran dalam jangka waktu tertentu [5]. Sehingga hasil belajar itu hasil maksimal dari siswa setelah melakukan proses pembelajaran dalam jangka waktu tertentu. Secara psikologis hasil tes belajar dapat memberikan kepuasan atas usaha yang telah dilakukan oleh siswa dalam menjawab tes.

Secara umum faktor yang mempengaruhi hasil belajar peserta didik di bagi menjadi 2 yaitu faktor internal dan faktor eksternal. Factor internal berarti factor yang ada pada dalam diri antara lain : sikap, minat, kecerdasan intelektual, bakat, motivasi dan semua factor yang ada dalam diri peserta didik [6]. Factor eksternal berarti factor yang ada di luar diri antara lain: lingkuan sekolah, lingkungan keluarga, dan lingkungan masyarakat [7]. Hasil belajar berbentuk nilai pada setiap mata pelajaran 
setelah terjadi proses belajar mengajar terutama pada pembelajaran IPA. Sehingga, nilai yang siswa dapat menunjukkan tinggi dan rendahnya hasil belajar IPA.

Kepanjangan dari kata IPA ialah ilmu pengetahuan alam sehingga dari kepanjangannya saja dapat disimpulkan bahwa IPA adalah pembelajaran yang mempelajari terkait alam semesta. Diperkuat oleh pendapat dari [8] sasaran utama pada dasarnya IPA ialah alam semesta. Ilmu Pengetahuan Alam merupakan terjemahan kata-kata Inggris, yaitu natural science, artinya ilmu pengetahuan alam. Jadi IPA atau science itu pengertiannya dapat disebut sebagai ilmu tentang alam atau ilmu yang mempelajari tentang peristiwaperistiwa yang terjadi di alam ini [9].

Ilmu pengetahuan alam (IPA) dapat memberikan peranan dan pengalaman pada siswa sebagai salah satu mata pelajaran yang terdapat di sekolah [10]. Melalui pembelajaran IPA, siswa tidak hanya menerima pengetahuan dari pendidik, tetapi peserta didik juga mencari tahu secara lansung apa yang sedang dipelajari melalui kegiatan percobaan. Oleh karena itu, pembelajaran IPA tidak hanya sebatas penyampaian materi pembelajaran saja, tetapi juga dibutuhkan aktivitas pembelajaran yang melibatkan siswa secara lansung melalui kegiatan percobaan yang memanfaatkan lingkungan sekitar.

Selama ini proses belajar mengajar IPA hanya menghafal fakta, prinsip atau teori saja [11]. Untuk itu diperlukan pengembangan model pembelajaran yang sesuai dengan karakteristik dari pembelajaran IPA dan menemukan atau menerapkan sendiri ide-idenya. Model pembelajaran yang akan digunakan salah satu faktor yang mempengaruhi keberhasilan dalam pembelajaran IPA.

Model pembelajaran adalah acuan dalam merancang aktivitas siswa dalam belajar sehingga dapat membantu siswa dalam menerima informasi, ide, keterampilan, cara berpikir dan mengemukakan ide [12].

Model pembelajaran disusun berdasarkan prinsip atau teori sebagai pijakan dalam mengembangkannya [13]. Model pembelajaran dapat dipilih polanya, artinya guru dapat memilih model yang akan digunakan untuk mencapai tujuan pembelajaran [14]. Guru dapat memilih model yang digunakan sesuai dengan tujuan yang ingin dicapai oleh pendidik. Model pembelajaran adalah mengorganisasikan pengalaman belajar yang kerangka konseptual dengan prosedur yang sistematik [15].

Rusman [3] model pembelajaran SAVI pertama kali diperkenalkan oleh Dave Miere. Menurut Meire (2002) model pembelajaran SAVI adalah pembelajaran yang menggabungkan gerakan fisik dengan aktivitas intelektual dengan menggunakan semua panca indra memberikan pengaruh besar terhadap pembelajaran. Teori yang mendukung pembelajaran SAVI adalah Accelerated Learning, teori otak kanan/kiri, teori otak triune, pilihan modalitas (visual, auditorial dan kinestetik), teori kecerdasan ganda, pendidikan (holistic) menyeluruh, belajar berdasarkan pengalaman, belajar dengan symbol[16].

SAVI kepanjangan dari kata somatis, auditori, visual dan intektual. Kata somatis berasal dari bahasa yunani yang bermakna tubuh [17]. Sehingga somatis berarti pembelajaran akan melibatkan tubuh dimana siswa akan melakukan pembelajaran dengan bergerak dan berbuat. Auditori bermakna belajar dengan cara mendengar atau menyimak dan dapat mengemukakan pendapat. Visual bermakna belajar dengan melihat atau mengamati dan membaca. Intelektual bermakna belajar dengan kemampuan berpikir siswa dengan menganalisis, menyelidiki, dan memecahkan masalah [8].

Karakteristik pada model pembelajaran SAVI telah mencangkup semua kegiatan siswa yang akan dilaksanakan dalam proses pembelajaran [15]. Dikarenakan pembelajaran SAVI sejalan dengan gerakan Accelerated Learning (AL), maka prinsipnya juga sejalan dengan Accelerated Learning (AL), Meier [16] mengajukan sejumlah prinsip pokok dalam belajar dengan menggunakan SAVI, yaitu sebagai berikut, (1) Pembelajaran melibatkan seluruh pikiran dan tubuh. (2) Pembelajaran berarti berkreasi bukan mengkonsumsi. (3) Kerjasama membantu proses pembelajaran. (4) Pembelajaran berlangsung pada benyak tingkatan secara simultan. (5) Belajar berasal dari mengerjakan pekerjaan itu sendiri dengan umpan balik. (6) Emosi positif sangat membantu pembelajaran. (7) Otak-citra menyerap informasi secara langsung dan otomatis.

Hasil observasi peneliti karakteristik kelas 4 di SDN 1 Sandik selama proses pembelajaran adalah (1) siswa aktif bermain tetapi tidak aktif dalam pembelajaran, (2) perhatian siswa lebih suka melihat gambar atau animasi berkaitan dengan kehidupan sehari-hari, (3) siswa sering membuat kegaduhan di dalam kelas dengan temannya. Dari karakteristik siswa yang aktif dan gemar berdiskusi sesuai dengan karakteristik pembelajaran IPA yang lebih banyak dalam percobaan dan model pemeblajaran SAVI memiliki karateristik yang memaksimalkan semua panca indra dan intelektual siswa. Dari karakteristik siswa dan pembelajaran IPA yang peneliti temukan sangat cocok menggunakan model pembelajaran SAVI.

Menurut teori Meier (2002) model pembelajaran SAVI dapat berpengaruh besar dalam pembelajaran selain itu menurut [18] menyatayakan bahwa model pembelajaran dapat mempengaruhi hasil belajar IPA siswa. Dari uraian-urangain di atas peneliti tertarik untuk mengambil judul "pengaruh model pembelajaran SAVI terhadap hasil belajar IPA siswa kelas IV di SDN 1 Sandik". 


\section{METODE PENELITIAN}

Penelitian ini merupakan penilitian Eksperimen, yaitu penelitian kuatitatif untuk mengukur hubungan sebab akibat. Jenis penelitian yang digunakan adalah Quasi Eksperimen Design Tipe Nonequivalent Control Group Design. Penelitian ini dilaksanakan di kelas IV-B SDN 1 Sandik yang terletak di Jln. Pariwisata Sandik, Kec. Batu Layar , Kab. Lombok Barat, Prov. Nusa Tenggara Barat. Penelitian ini dilaksanakan pada April sampai dengan bulan Mei atau bertepatan dengan pelaksanaan pembelajaran semester Genap Tahun Pelajaran 2020/2021. Populasi dalam penelitian ini adalah 87 siswa. Jumlah keseluruhan sampel adalah 60 siswa.

Penelitian ini dilakukan terhadap 2 kelas yakni kelas eksperimen dan kelas kontrol (Pembanding). kelas IV B sebagai kelas eksperimen berjumlah 30 siswa dan kelas IV C sebagai kelas kontrol berjumlah 30 siswa. Pada kelas eksperimen akan diberikan perlakukan berupa pembelajaran menggunakan model pembelajaran SAVI sedangkan pada kelas kontrol (Pembanding) diberikan perlakuan berupa tidak menggunakan model pembelajaran SAVI. Untuk mendapatkan data awal peniliti akan memberikan tes pre-test dan untuk mendapatkan data akhir peneliti memberikan tes post-test terhadap kedua kelas. Dengan demikian rancangan penelitian secara sederhananya sebagai berikut :

Tabel 1. Desain Penelitian

\begin{tabular}{clll}
\hline Kelompok & Pre-Test & Perlakuan & Post-Test \\
\hline Eksperimen & $\mathrm{O}_{1}$ & $\mathrm{X}$ & $\mathrm{O}_{2}$ \\
Kontrol & $\mathrm{O}_{3}$ & & $\mathrm{O}_{4}$ \\
\hline
\end{tabular}

Kelas eksperimen akan diberikan
perlakuan dengan menggunakan model pembelajaran Somatic, Auditory, Visual, dan Intellectually (SAVI), sedangkan kelas kontrol diberikan perlakuan dengan menggunakan pembelajaran konvensional. Selanjutkan kedua kelas akan diberikan tes setelah diberikan perlakuan.

Prosedur penelitian ini dilaksanakan dalam tiga tahap penelitian, yaitu : tahapan pertama pendahuluan: (a) Peneliti melakukan survey ke sekolah yaitu dengan melihat hasil belajar dari peserta didik dan model yang digunakan oleh pendidik dalam pembelajaran IPA di kelas IV. (b) Mencari masalah yang ada dalam proses pembelajaran. (c) Menganalisis konsep yang akan dikaji oleh peneliti. (d) Menyusun semua instrument yang akan digunakan oleh peneliti. (e) Melakukan uji coba terhadap semua instrumen yang telah disusun kemudian di analisis.

Tahapan kedua pelaksanaan: Pada tahap ini instrument yang telah di uji coba dan di analisis akan diberikan kepada siswa sebagai pre-test yang akan menjadi data awal dan untuk mengetahui kemampuan awal siswa sebelum diberikan perlakukan oleh peneliti. Kemudian diberikan perlakuakan yaitu pembelajaran menggunakan model pembelajaran SAVI untuk kelas eksperimen dan diberikan perlakuakan untuk kelas kontrol dengan menggunakan model pembelajaran konvensional. Setelah kedua kelas diberikan perlakukan maka peneliti akan memberikan tes akhir atau post-test kepada kedua kelas tersebut.

Tahapan akhir : Pada tahap ini peneliti menganalisis dari data tes awal (pre-test) dan tes akhir (post-test) dengan menggunakan uji statistik. Kemudian peneliti akan membuat kesimpulan dari hasil uji statistik yang telah dilakukan.

Variabel penelitian adalah suatu atribut atau kegiatan yang mempunyai variasi tertentu yang ditetapkan oleh peneliti untuk dipelajari dan kemudian ditarik kesimpunnya [13]. Variabel yang diamati dalam penelitian ini adalah variabel terikat (variabel dependen) dan variabel bebas (variabel independen). Variabel independen (variabel bebas) sering disebut sebagai stimulus, predictor, antecedent. Variabel bebas adalah variabel yang mempengaruhi variabel dependen atau variabel terikat [13]. Variabel dependen (variabel terikat) sering disebut juga varibel output, kriteria, konsekuensi. Variabel terikat adalah variabel yang dipengaruhi karena adanya variabel bebas. Adapun yang menjadi variabel bebas dalam penelitian ini adalah model pembelajaran SAVI (X) sedangkan variabel terikat pada penelitian ini adalah hasil belajar (Y) siswa dalam mata pelajaran IPA di kelas IV.

Untuk melakukan penelitian terlebih dahulu peneliti menentukan populasi dan sampel. Populasi adalah wilayah generalisasi yang terdiri atas: obyek/subjek yang mempunyai kualitas dan karateristik tertentu yang ditetapkan oleh peneliti untuk dipelajari dan kemudian ditarik kesimpulan [13]. Menurut para ahli lain populasi adalah kelompok besar yang memiliki karateristik yang sama [19].

Berdasarkan pendapat dari para ahli dapat peneliti simpulkan populasi adalah keseluruhan objek/subjek yang mempunyai karateristik yang sama sesuai yang ditetapkan oleh peneliti. Sehubungan dengan penelitian ini, maka yang menjadi populasi dalam penelitian ini adalah seluruh siswa kelas IV SDN 1 Sandik tahun pelajaran 2020/2021 berjumlah 87 siswa.

Sampel adalah bagian dari jumlah dan karateristik yang dimiliki oleh populasi tersebut [13]. Menurut para ahli lain sampel adalah sebagian dari populasi yang diambil dengan cara-cara tertentu [19].

Tenik sampling yang digunakan dalam penelitian ini adalah nonprobability sampling. Nonprobability sampling adalah teknik pengambilan sampel yang tidak memberikan peluang/kesempatan 
yang sama bagi setiap unsur (anggota) populasi untuk dipilih menjadi anggota sampel [13]. Adapun jenis dari teknik nonprobability sampling yang digunakan adalah sampling purposive. Sugiyono [13] sampling purposive adalah teknik penentuan sampel dengan pertimbangan tertentu. Untuk menentukan sampel peneliti mendapatkan pertimbangan oleh pedidik di sekolah untuk memilih kelas yang memiliki kemampuan yang hampir sama. Sehingga peneliti mengambil kelas IV B sebagai kelas eksperimen berjumlah 30 siswa dan kelas IV C sebagai kelas kontrol berjumlah 30 siswa. Jumlah keseluruhan sampel adalah 60 siswa.

Penelitian ini menggunakan tiga metode pengumpulan data yaitu laporan observasi, dokumentasi dan tes. Adapun instrument penelitian yang digunakan dalam penelitian antara lain lembar pengamatan (observasi), tes dan dokumentasi. Instrument penelitian yang baik harus memenuhi dua persyaratan penting yaitu, valid dan reliabel.

Adapun analisis data pada penelitian ini menggunakan SPSS versi 21.0 for windows. Uji statistik pada penelitian ini menggunakan uji $\mathrm{t}$ dan uji gain ternormalisasi. Uji $\mathrm{t}$ digunakan untuk mengetahui apakah terdapat perbedaan rata-rata dua sampel (dua kelompok) yang berpasangan atau berhubungan. Ketentuan dalam uji statistik menggunakan uji t (paired-sample t-test) yaitu jika nilai sig.. $<0,05$ mata terdapat perbedaan yang signifikan antara rata-rata pada data pretest dan posttest atau Ho ditolak. Jika sig. > 0,05 maka tidak terdapat perbedaan yang signifikan antara rata-rata pretest dan posttest atau Ho diterima. Uji gain ternormalisasi untuk menghitung seberapa besar pengaruh yang diberikan oleh perlakukan tersebut.

\section{HASIL DAN PEMBAHASAN}

\section{Uji Validitas Instrument Tes}

Penyebaran instrumen tes dilakukan di SDN 2 Sandik yang segugus dengan sekolah tempat penelitian. Dalam penelitian ini jumlah soal yang akan di uji adalah 50 soal kepada 23 siswa sebagai responden. Pengujian akan dilakukan mengguakan SPSS versi 21.0 for windows. Dari hasil perhitungan tersebut menunjukkan bahwa dari 50 soal ada 24 soal yang valid.

\section{Uji Reliabilitas Instrument Tes}

Instrumen yang dikatakan reliabel yaitu instrumen yang bila digunakan beberapa kali untuk mengukur objek yang sama, akan menghasilkan data yang sama. Pengujian akan dilakukan mengguakan SPSS versi 21.0 for windows. Kriteria uji reliabilitas yang digunakan adalah apabila sebagai berikut: (a) Jika nilai $\alpha>0,700$ berati tes hasil belajar yang sedang diuji reliabilitasnya dinyatakan telah memiliki reliabilitas yang tinggi (reliabel). (b) Jika nilai $\alpha<0,700$ berarti tes hasil belajar yang sedang diuji reliabilitasnya dinyatakan belum memiliki reliabilitas yang tinggi (un-reliabel). Adapun hasil uji sebagai berikut :

Tabel 2. Hasil Uji Reliabilitas

\begin{tabular}{c} 
Reliability Statistics \\
\hline Cronbach's Alpha N Of Items
\end{tabular}

apat .899 24

t pada tabel di atas bahwa hasil uji realibitas sebesar $0,899>0,700$ yang artinya soal dapat dikatakan reliabel. Berdasarkan klasifikasi reliabilitas soal diatas artinya derajat keterandahan instrumen berada pada kategori sangat tinggi.

\section{Pelaksanaan Penelitian}

Penelitian ini merupkan penelitian eksperimen jenis Quasi Eksperimen Design Tipe Nonequivalent Control Group Design. Kegiatan penelitian dilaksanakan pada bulan Mei tahun 2021 pada siswa kelas V di SDN 1 Sandik yang digunakan peneliti untuk melakukan penelitian. Penentuan kelas eskperimen dan kelas kontrol yang digunakan adalah sampling purposive. Sugiyono [13] sampling purposive adalah teknik penentuan sampel dengan pertimbangan tertentu. Untuk menentukan sampel peneliti mendapatkan pertimbangan oleh pedidik di sekolah untuk memilih kelas yang memiliki kemampuan yang hampir sama. Sehingga peneliti mengambil kelas IV B sebagai kelas eksperimen berjumlah 30 siswa dan kelas IV C sebagai kelas kontrol berjumlah 30 siswa. Jumlah keseluruhan sampel adalah 60 siswa. Pada penelitian ini diadakan 4 kali pertemuan, yaitu 2 kali pertemuan untuk pembelajaran macam-macam gaya dan masingmasing 1 kali pertemuan untuk mengambil data pretest dan post-test.

Kelas eksperimen merupakan kelas yang diberi perlakuan berupa penggunaan model pembelajarin SAVI pada pembelajaran macammacam gaya. Kelas dijadikan kelas eksperimen adalah VB SDN 1 Sandik yang berjumlah 30 siswa dan semua siswa ikut serta dalam pengambilan data penelitian untuk pre-test dan post-test. Pada pelaksanaan penelitian eksperimen ini, sebelum diberi perlakuan terlebih dahulu diberikan tes awal (pre-test) untuk mengetahui kemampuan siswa sebelum diberikan perlakuan. Pemberian perlakua pada kelas eksperimen sebayak 2 kali dan dilanjutkan dengan tes akhir (post-test) untuk mengetahui kemampuan siswa setelah mengikuti pembelajaran menggunakan model pembelajaran SAVI.

Proses pembelajaran pada kelas eksperimen diawali seperti pada umumnya, yang membedakan adalah penggunaan model pembelajaran SAVI pada pembelajaran macam-macam gaya. Pertama-tama siswa menonton materi tentang macam-macam gaya, kemudian membagi siswa menjadi beberapa kelompok dan guru memberikan kesempatan siswa berdiskusi dengan teman sekelompok terkait macam- 
macam gaya. Guru membagikan LKS kepada siswa untuk menjawab LKS secara berkelompok.

Kelas kontrol merupakan kelas yang diberi perlakuan berupa tidak menggunakan model pembelajarin SAVI pada pembelajaran macammacam gaya. Kelas dijadikan kelas kontrol adalah VC SDN 1 Sandik yang berjumlah 30 siswa dan semua siswa ikut serta dalam pengambilan data penelitian untuk pre-test dan post-test. Pada pelaksanaan penelitian kontrol ini, sebelum diberi perlakuan terlebih dahulu diberikan tes awal (pretest) untuk mengetahui kemampuan siswa sebelum diberikan perlakuan. Pemberian perlakua pada kelas eksperimen sebayak 2 kali dan dilanjutkan dengan tes akhir (post-test) untuk mengetahui kemampuan siswa setelah mengikuti pembelajaran tanpa menggunakan model pembelajaran SAVI.

Proses pembelajaran pada kelas kontrol diawali seperti pada umumnya, menggunaan model pembelajaran konvensional pada pembelajaran macam-macam gaya. Pertama-tama siswa mendengar penjelasan guru materi tentang macammacam gaya, kemudian membagi guru memberikan kesempatan siswa untuk bertanya dan Guru membagikan LKS kepada siswa untuk menjawab LKS secara individu.

Uji prasyarat yang digunakan adalah uji normalitas dan homogenitas. Untuk menghitung uji tersebut peneliti telah memiliki hasil penelitian. Penelitian dilakukan pada kelas IV di SDN 1 Sandik. Kelas IVB sebagai kelas eksperimen berjumlah 30 siswa dan kelas IVC sebagai kelas kontrol berjumlah 30 siswa.

Berdasarkan hasil perhitungan bahwa nilai rata-rata hasil belajar kelas eksperimen mengalami peningkatan yaitu dari nilai pre-test sebesar 56,4 dan nilai posttest sebesar 71,56667. Selanjutnya, untuk mengetahui hipotesis yaitu adanya pengaruh model pembelajaran somatic, auditory, visual, intelektual (SAVI) yang terjadi perlu diketahui juga data yang terdapat pada kelas kontrol.

Berdasarkan hasil perhitungan bahwa nilai rata-rata hasil belajar kelas kontrol mengalami peningkatan yaitu dari nilai pre-test sebesar 56,26667 dan nilai posttest sebesar 59,86667. Kemudian, guna lebih jelasnya membuktikan bahwa adanya peningkatan maka dilakukan uji t, sebelum dilakukan uji $\mathrm{t}$ data harus memenuhi kriteria yaitu data harus berdistribusi normal dan homogen.

\section{Uji Normalitas}

Peneliti menggunakan uji Kolmogorov smirnov. Pengujian akan dilakukan mengguakan SPSS versi 21.0 for windows.

Berdasarkan nilai signifikansi pre-test kelas eksperimen adalah sebesar 0,560>0,05, sehingga dapat disimpulkan bahwa data pretest tersebut berdistribusi normal. Nilai signifikansi post-test kelas eksperimen adalah sebesar 0,268 > 0,05 sehingga dapat disimpulkan bahwa data posttest berdistribusi normal. Nilai signifikansi pre-test kelas kontrol adalah sebesar 0,794 >0,05, sehingga dapat disimpulkan bahwa data pretest tersebut berdistribusi normal. Nilai signifikansi post-test kelas control adalah sebesar $0,732>0,05$ sehingga dapat disimpulkan bahwa data posttest berdistribusi normal.

\section{Uji Homogenitas}

Uji homogenitas varians adalah teknik analisis data untuk menguji apakah data berasal dari populasi yang homogen atau tidak. Uji homogenitas variansi sangat diperlukan sebelum membandingkan dua kelompok atau lebih, agar perbedaan yang ada bukan disebabkan oleh adanya perbedaan data dasar (ketidak homogenan kelompok yang dibandingkan). Ada beberapa rumus yang bisa digunakan untuk uji homogenistas variansi di antaranya: uji Harley, uji Cohran, Uji Levene, dan uji Bartlett [20]. Peneliti menggunakan Uji Levene Pengujian akan dilakukan mengguakan SPSS versi 21.0 for windows.

Berdasarkan nilai signifikansi pre-test kelas eksperimen dan kontrol adalah sebesar 0,109 > 0,05, sehingga dapat disimpulkan bahwa data pretest tersebut berdistribusi homogen. Nilai signifikansi post-test kelas eksperimen dan kontrol adalah sebesar $0,506>0,05$ sehingga dapat disimpulkan bahwa data posttest berdistribusi homogen.

\section{Hasil Observasi Penggunaan Model Pembelajaran SAVI}

Gambaran kegiatan siswa dalam proses pembelajaran IPA dengan menggunakan penerapan model SAVI pada kelas eksperimen dapat dilihat dari Hasil analisis terhadap aktivitas belajar siswa. Data tentang aktivitas belajar siswa diperoleh melalui pengamatan langsung oleh peneliti pada waktu pembelajaran di kelas.

Skor tertinggi untuk setiap butir observasi terhadap aktivitas siswa adalah 4 , sedangkan jumlah butir observasi adalah 10, maka skor tertinggi adalah 40. Kriteria penilaian terhadap aktivitas siswa yaitu kategori kurang nilainya 1 , kategori sedang nilainya 2 , kategori baik nilanya 3, dan katagori sangat baik nilainya 4. Penentuan hasil dengan jumlah skor di dapatkan dibagi dengan skor total dan di kali 100.

Observasi dilakukan untuk mengukur ketercapaian pelaksanaan penggunaan model pembelajaran SAVI saat perlakuan dilakukan. Pelaksanaan observasi ini dilakukan oleh observer yang mengisi lembar observasi saat pelaksanaan perlakuan. Pada penelitia ini yang menjadi observer adalah peneliti sendiri.

Dapat dilihat pada tabel 3 di atas Berdasarkan hasil observasi aktivitas siswa pada perlakuan I adalah 29 skor dengan kriteria baik. Berdasarkan hasil observasi aktivitas siswa pada perlakuan II adalah 32 skor dengan kriteria sangat 
baik, dari hasil tersebut terjadi peningkatan hasil observasi dari perlakuan I ke II menjadi semakin baik. Berdasarkan hasil observasi aktivitas guru pada perlakuan I adalah 31 skor dengan kriteria baik Berdasarkan hasil observasi aktivitas guru pada perlakuan II adalah 33 skor dengan kriteria sangat baik, dari hasil tersebut terjadi peningkatan hasil observasi dari perlakuan I ke II menjadi semakin baik.

Tabel 3. Hasil Observasi

\begin{tabular}{ccccc}
\hline & \multicolumn{2}{c}{ Guru } & \multicolumn{2}{c}{ Siswa } \\
& Total & \multicolumn{3}{c}{ Total } \\
Perlakuan & Skor & Kriteria & Skor & Kriteria \\
\hline I & 31 & Baik & 29 & Baik \\
II & 33 & $\begin{array}{c}\text { Sangat } \\
\text { Baik }\end{array}$ & 32 & $\begin{array}{c}\text { Sangat } \\
\text { Baik }\end{array}$ \\
\hline
\end{tabular}

\section{Hasil Uji Hipotesis}

Berdasarkan hasil uji normalitas dan homogenitas data hasil belajar IPA siswa kedua kelas terdistribusi normal dan homogen. Pengujian hipotesis dilakukan dengan uji statistic parametrik. Uji statistic paramerik yang digunakan adalah uji $\mathrm{t}$ (paired-sample t-test). Pengujian akan dilakukan mengguakan SPSS versi 21.0 for windows.

Pengujian hipotesis dilakukan untuk mengetahui adakah pengaruh penggunaan model pembelajaran SAVI terhadap hasil belajar IPA siswa. Adapun ketentuan dalam pengujian, yaitu jika nilai sig.. $<0,05$ mata terdapat perbedaan yang signifikan antara rata-rata pada data pretest dan posttest atau Ho ditolak . Jika sig. > 0,05 maka tidak terdapat perbedaan yang signifikan antara rata-rata pretest dan posttest atau Ho diterima.

Berdasarkan hasil dari uji $\mathrm{t}$ pada kelas eksperimen adalah $-6,931$ dan $t_{\text {tabel }}$ adalah|2,045| sehingga diketahui bahwa nilai $t_{\text {hitung }}$ pada kelas eksperimen 6,931 > 2,045, maka ada perbedaan nilai rata-rata siswa sebelum diberikan perlakuan dan setelah diberikan perlakuan (penggunaan model pembelajaran SAVI).

Hasil dari uji t pada kelas control adalłh 5,453 dan $t_{\text {tabel }}$ adalah 2.045. sehingga diketahui bahwa nilai thitung pada kelas kontrol 5,453 > 2,045, maka ada perbedaan nilai rata-rata siswa sebelum diberikan perlakuan dan setelah diberikan perlakuan (penggunaan model pembelajaran konvensional).

\section{Hasil Uji Gain Ternormalisasi}

Pengujian gain ternormalisasi dilakukan untuk mengetahui seberapa besar pengaruh dari model pembelajaran SAVI terhadap hasil belajar IPA siswa. Adapun pengujian gain ternormalisasi di lakukan terhadap data post-test hasil belajar IPA siswa.
Tabel 4. Tabel Bantu Untuk Mencari Uji Gain Ternormalisasi

\begin{tabular}{|c|c|c|l|}
\hline Kelas & $\begin{array}{c}\text { Mean } \\
\text { Skor Pre- } \\
\text { Test }\end{array}$ & $\begin{array}{c}\text { Mean Skor } \\
\text { Post-test }\end{array}$ & $\begin{array}{l}\text { Skor } \\
\text { maksimal }\end{array}$ \\
\hline Eskperimen & 56,4 & 71,56667 & 100 \\
\hline
\end{tabular}

$$
\begin{aligned}
& \langle\mathrm{g}\rangle=\frac{\text { mean skor posttest }- \text { mean skor pretest }}{\text { Mean skor ideal }- \text { mean skor pretest }} \\
& \langle\mathrm{g}\rangle=\frac{71,56667-56,4}{100-56,4}
\end{aligned}
$$

$\langle\mathrm{g}\rangle=\frac{15,16667}{43,6}$

$\langle\mathrm{g}\rangle=0,3$

Pada pehitungan di atas dapat dilihat nilai uji gain ternormalisasi mencapai angka 0,3 sesuai dengan katagori skor gain ternormalisasi dimana angka tersebut menunjukkan bahwa pengaruh yang ditimbukan oleh model pembelajaran SAVI terhadap hasil belajar IPA siswa termasuk kedalam katagori sedang. Dapat disimpulkan bahwa ada pengaruh yang positif dari penggunaan model pembelajaran SAVI terhadap hasil belajar IPA siswa kelas IV SDN 1 Sandik tahun pelajaran 2020/2021.

\section{KESIMPULAN}

Berdasarkan hasil nilai rata-rata kelas eksperimen mengalami perubahan yaitu dari nilai pre-test sebesar 56,40 dan nilai posttest sebesar 71,57. Berdasarkan hasil pre-test dan post-test unsur yang paling berpengaruh pada model pembelajaran Somatic, Auditory, Visual, Dan Intellectually (SAVI) adalah unsur Visual. Hasil analisis data perhitungan statistic dengan menggunakan uji t (paired-sample ttest). Hasil pehitungan uji hipotesis diperoleh $\mathrm{H}_{\mathrm{a}}$ diterima dan $\mathrm{H}_{0}$ ditolak. Uji gain ternormalisasi dilakukan untuk mengetahui seberapa besar pengaruh. Hasil uji gain ternormalisasi yang peneliti dapat sebesar 0,3 termasuk kedalam katagori sedang. Berdasarkan hasil analisis data penelitian yang sudah dilakukan maka dapat disimpulkan bahwa adanya pengaruh dari penggunaan model pembelajaran SAVI terhadap hasil belajar IPA.

\section{DAFTAR PUSTAKA}

[1] Sayekti, R. (2018). Pengaruh Model Pembelajaran Somatic, Auditory, Visual, Intelektual (Savi) Terhadap Hasil Belajar Matematika Siswa Kelas V Min 9 Bandar Lampung (Doctoral dissertation, UIN Raden Intan Lampung).

[2] Sulfemi, W. B. (2019). Pengaruh kemampuan pedagogik guru dengan hasil belajar ips.

[3] Rusman. (2011). Model-model pembelajaran: Mengembangkan profesionalisme guru. Rajawali Pers/PT Raja Grafindo Persada. 
[4] Komariyah, S., \& Laili, A. F. N. (2018). Pengaruh kemampuan berpikir kritis terhadap hasil belajar matematika. JP3M (Jurnal Penelitian Pendidikan dan Pengajaran Matematika), 4(2), 53-58.

[5] Nurrita, T. (2018). Pengembangan media pembelajaran untuk meningkatkan hasil belajar siswa. MISYKAT: Jurnal Ilmu-ilmu AlQuran, Hadist, Syari'ah dan Tarbiyah, 3(1), 171-210.

[6] Yulianti, H., Iwan, C. D., \& Millah, S. (2018). Penerapan Metode Giving Question And Getting Answer Untuk Meningkatkan Hasil Belajar Peserta Didik Pada Mata Pelajaran Pendidikan Agama Islam. Jurnal Penelitian Pendidikan Islam, [SL], 6(2), 197-216.

[7] Nurhasanah, S., \& Sobandi, A. (2016). Minat belajar sebagai determinan hasil belajar siswa. Jurnal Pendidikan Manajemen Perkantoran (JPManper), 1(1), 128-135.

[8] Ariasih, N. K., Abadi, I. B. G. S., \& Asri, I. G. A. S. (2013). Pengaruh Model Pembelajaran Kooperatif SAVI Berbantuan Media Konkret Terhadap Hasil Belajar IPA SD. MIMBAR PGSD Undiksha, 2(1).

[9] Muakhirin, B. (2014). Peningkatan hasil belajar IPA melalui pendekatan pembelajaran inkuiri pada siswa SD. Jurnal ilmiah guru caraka olah pikir edukatif, (1).

[10] Hamdu, G., \& Agustina, L. (2011). Pengaruh motivasi belajar siswa terhadap prestasi belajar IPA di sekolah dasar. Jurnal penelitian pendidikan, 12(1), 90-96.

[11] Tias, I. W. U. (2017). Penerapan model penemuan terbimbing untuk meningkatkan hasil belajar IPA siswa sekolah dasar. DWIJA CENDEKIA: Jurnal Riset Pedagogik, 1(1).

[12] Marliani, N. (2015). Peningkatan Kemampuan Berpikir Kreatif Matematis Siswa Melalui Model Pembelajaran Missouri Mathematics Project (MMP). Formatif: Jurnal Ilmiah Pendidikan MIPA, 5(1).

[13] Sugiyono, M. P. P., \& Kuantitatif, P. (2009). Kualitatif, dan R\&D, Bandung: Alfabeta. Cet. Vii.

[14] Nurdyansyah, N., \& Fahyuni, E. F. (2016). Inovasi model pembelajaran sesuai kurikulum 2013.

[15] Yanto, E. N. A. (2017). Penggunaan Model Pembelajaran SAVI Untuk Meningkatkan Prestasi Belajar IPS Pada Siswa Kelas V SD Al Husna Kota Madiun. Jurnal Kependidikan Dasar Islam Berbasis Sains, 2(2), 33-42.

[16] Sutarna, N. (2018). Pengaruh Model Pembelajaran SAVI (Somatic Auditory Visual Intellectualy) Terhadap Hasil Belajar Siswa Kelas IV Sekolah Dasar. Profesi Pendidikan Dasar, 5(2), 119-126.

[17] Milawati, T. (2011). Peningkatan kemampuan anak memahami drama dan menulis teks drama melalui model pembelajaran somatis auditori visual intelektual (SAVI). Jurnal penelitian pendidikan, 14(2), 70-78.

[18] Alfiani, D. A. (2016). Penerapan Model Pembelajaran SAVI (Somatis, Auditori, Visual, Intelektual) Terhadap Hasil Belajar Anak Usia Dini. Awlady: Jurnal Pendidikan Anak, 2(1).

[19] Amalia, M., \& Hastuti, S. (2020). Pengaruh Model Pembelajaran SAVI Terhadap Hasil Belajar IPA Siswa Kelas V. Jurnal Pendidikan Fisika Dan Sains (JPFS), 3(1), 1-5. [19] neni Hasnunidah, Metodologi Penelitian Pendidikan. 2017.

[20] Usmadi, U. (2020). PENGUJIAN PERSYARATAN ANALISIS (UJI HOMOGENITAS DAN UJI NORMALITAS). Inovasi Pendidikan, 7(1). 